\title{
Sumoylation of HDAC2 promotes NF-KB-dependent gene expression
}

\author{
Tobias Wagner ${ }^{1}$, Nicole Kiweler ${ }^{2}$, Katharina Wolff ${ }^{1}$, Shirley K. Knauer ${ }^{3}$, André \\ BrandI $^{1}$, Peter Hemmerich ${ }^{4}$ Jan-Hermen Dannenberg ${ }^{5}$, Thorsten Heinzel ${ }^{1}$, Günter \\ Schneider ${ }^{6}$ and Oliver H. Krämer ${ }^{2}$

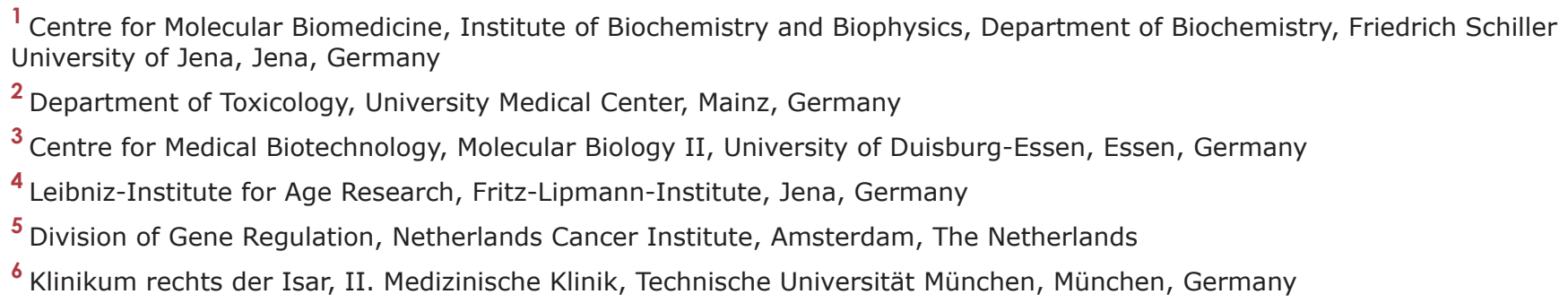

Correspondence to: Oliver H. Krämer, email: okraemer@uni-mainz.de

Keywords: Histone deacetylase 2, p53, p65, RSK1, SUMO

Received: January 02, $2015 \quad$ Accepted: January 04, $2015 \quad$ Published: January 21, 2015

This is an open-access article distributed under the terms of the Creative Commons Attribution License, which permits unrestricted use, distribution, and reproduction in any medium, provided the original author and source are credited.

\section{ABSTRACT}

The transcription factor nuclear factor-kB (NF-KB) is crucial for the maintenance of homeostasis. It is incompletely understood how nuclear NF-KB and the crosstalk of NF-KB with other transcription factors are controlled. Here, we demonstrate that the epigenetic regulator histone deacetylase 2 (HDAC2) activates NF-KB in transformed and primary cells. This function depends on both, the catalytic activity and an intact HDAC2 sumoylation motif. Several mechanisms account for the induction of NF-kB through HDAC2. The expression of wild-type HDAC2 can increase the nuclear presence of NF-KB. In addition, the ribosomal S6 kinase 1 (RSK1) and the tumor suppressor p53 contribute to the regulation of NF-KB by HDAC2. Moreover, TP53 mRNA expression is positively regulated by wild-type HDAC2 but not by sumoylation-deficient HDAC2. Thus, sumoylation of HDAC2 integrates NF-KB signaling involving p53 and RSK1. Since HDAC2-dependent NF-KB activity protects colon cancer cells from genotoxic stress, our data also suggest that high HDAC2 levels, which are frequently found in tumors, are linked to chemoresistance. Accordingly, inhibitors of NF-kB and of the NF-KB/p53-regulated anti-apoptotic protein survivin significantly sensitize colon carcinoma cells expressing wild-type HDAC2 to apoptosis induced by the genotoxin doxorubicin. Hence, the HDAC2-dependent signaling node we describe here may offer an interesting therapeutic option.

\section{INTRODUCTION}

Transcription factors belonging to the NF- $\mathrm{KB}$ family (p65/RelA, p105/p50, p100/p52, RelB, and c-Rel) regulate important physiological processes, such as cell proliferation, development, and immunity. Accordingly, dysregulation of NF- $\mathrm{KB}$ proteins can contribute to severe diseases, including cancer [1-3]. The pro-survival role of NF- $\mathrm{KB}$ can counteract tumor suppressive pathways, e.g., gene expression signatures induced through p53
[4]. Activation of canonical NF- $\mathrm{kB}$ signaling involves ubiquitinylation and phosphorylation events. IKB kinases (IKKs) become activated and phosphorylate inhibitor of NF- $\kappa \mathrm{B}$ proteins (I $\mathrm{KBs}$ ), which are subsequently degraded by the proteasome. The released NF- $\mathrm{KB}$ proteins shuttle into the nucleus to activate specific sets of genes [2]. Other activation modes for NF- $\mathrm{kB}$ are the non-canonical/ alternative and the atypical pathway. The latter is connected to genotoxic stress which activates p53 and NF$\kappa \mathrm{B}[4]$. The apical stress sensor kinase ATM, IKK $\varepsilon$, and 
IKK $\gamma / \mathrm{NEMO}$ are further players in the control of atypical $\mathrm{NF}-\kappa \mathrm{B}$ activation [5-8]. Furthermore, increasing evidence shows that p53 directly controls various NF- $\kappa B$-dependent signaling cascades ultimately determining the balance between cell survival and cell death [4, 9-13].

Lysine/histone deacetylases (KDACs/HDACs) are important epigenetic regulators that catalyze the deacetylation of $\varepsilon-\mathrm{N}$-acetylated lysine residues of numerous proteins. The 18 HDACs in humans are sorted into four classes according to phylogenetic derivation, with HDAC2 being a member of class I [14]. On a gene regulatory level, deacetylated histones are traditionally correlated with condensed, transcriptionally inactive chromatin. However, HDAC activity can have positive effects on transcription as well [15]. Furthermore, dynamically regulated non-histone protein acetylation/ deacetylation cycles determine gene expression as well as the stability, localization, interaction, and DNA binding affinity of proteins [16]. HDAC1, HDAC2, HDAC4, and SIRT1, are posttranslationally modified by the small ubiquitin-related modifier (SUMO), linking sumoylation to epigenetic regulation [17-20]. Sumoylation is the posttranslational formation of isopeptide bonds between the SUMO C-terminus and the NH2-group of a lysine residue by an enzymatic machinery consisting of a single E1-activating enzyme, the SUMO E2-conjugase UBC9, and several SUMO E3-ligases [21, 22].

P53 functions are antagonized by HDAC2 through its sumoylation-dependent recognition of $\mathrm{p} 53$ and a subsequent deacetylation of p53 at K320 [19, 23]. As a result, HDAC2 but not HDAC2 $2^{\mathrm{K} 462 \mathrm{R}}$ enhances the cellular tolerance to DNA damage induced by chemotherapeutics [19]. Less is known about HDAC2 influencing NF$\kappa \mathrm{B}$-dependent gene expression. Contradictory reports show both, positive and negative influences of HDAC2

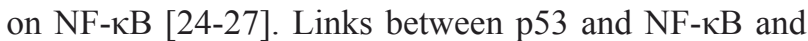
their direct interactions are well established $[4,9,10$, 13, 28, 29]. However, there is still limited information on the mechanisms, posttranslational modifications, and upstream regulators orchestrating the $\mathrm{NF}-\kappa \mathrm{B} / \mathrm{p} 53$ crosstalk [4]. The latter is often found in cells exposed to genotoxic stress which can induce p53 and IKKs triggering NF- $\kappa \mathrm{B}$ activation [1]. Furthermore, the kinase RSK1 modulates the $\mathrm{p} 53$-dependent activation of NF- $\mathrm{KB}[11,12]$. It appears possible that histone acetyltransferases (HATs), HDACs, and further epigenetic regulators control NF- $\mathrm{BB}$ and its crosstalk with p53.

Here, we demonstrate the importance of HDAC2 for NF- $\mathrm{NB}$-dependent gene expression and analyzed the effect of HDAC2 sumoylation in this process. Indeed, $\mathrm{NF}-\kappa \mathrm{B}$-dependent gene expression is increased in the presence of wild-type HDAC2. Sumoylation-deficient HDAC $2^{\mathrm{K} 462 \mathrm{R}}$ though fails to propel NF- $\kappa \mathrm{B}$ activity. In addition, we reveal that p53 and RSK1 are prerequisites for the positive effect of HDAC2 on NF- $\kappa$ B in colon cancer cells. Furthermore, DNA binding assays show an increased recruitment of $\mathrm{p} 53$ to $\mathrm{NF}-\kappa \mathrm{B}$ consensus binding sequences. Enhanced expression of a subset of $\mathrm{NF}-\kappa \mathrm{B}$ target genes in cells expressing HDAC2, but not in cells carrying HDAC2 ${ }^{\mathrm{K} 462 \mathrm{R}}$, suggests a novel, sumoylationdependent regulatory mechanism for $\mathrm{p} 65$. This molecular mechanism appears important for the survival of cancer cells exposed to genotoxic stress.

\section{RESULTS}

\section{NF-кB-regulated transcription is enhanced by HDAC2 sumoylation}

Since sumoylation of HDAC2 can control p53 [19], we speculated that HDAC2 sumoylation may also regulate other transcription factors. Activity of $\mathrm{NF}-\kappa \mathrm{B}$ was previously described to be regulated by HDAC2 and thus seemed to be a worthwhile target to test for effects of HDAC2 sumoylation. To check this hypothesis, we cotransfected a NF- $\kappa \mathrm{B}$ luciferase reporter with expression vectors encoding wild-type HDAC2 or HDAC2 ${ }^{\mathrm{K} 462 \mathrm{R}}$ [19]. Expression of HDAC2 significantly activated the NF$\kappa \mathrm{B}$-dependent reporter while HDAC $2^{\mathrm{K} 462 \mathrm{R}}$ did not induce $\mathrm{NF}-\kappa \mathrm{B}$ activity under identical conditions (Figure 1A). Likewise, HDAC2, but not HDAC2 ${ }^{\mathrm{K} 462 \mathrm{R}}$ overexpression caused induction of $\mathrm{NF}-\kappa \mathrm{B}$ luciferase reporters with different numbers of $\kappa \mathrm{B}$ consensus DNA binding sites (Supplementary Figure S1A).

Next, we analyzed whether HDAC2 can also activate NF- $\kappa \mathrm{B}$-dependent gene expression in other cell types including non-transformed cells. We conducted experiments with primary murine embryonic fibroblasts (MEFs). Murine HDAC2 shows conservation of the sumoylation site but differs from the human sequence at two amino acid positions. Therefore, the murine Hdac2 cDNA was cloned into the same expression vector system we used to express human HDAC2. Like in the transformed cells, murine HDAC2, but not $\mathrm{HDAC} 2^{\mathrm{K} 462 \mathrm{R}}$, activated the $\mathrm{NF}-\kappa \mathrm{B}-$ dependent reporter (Figure 1B). Additionally, transient expression of HDAC2 in the HDAC2-negative RKO cell line [30] induced $\mathrm{NF}-\kappa \mathrm{B}$ activity, while the sumoylation-deficient mutant HDAC2 ${ }^{\mathrm{K} 462 \mathrm{R}}$ did not (Figure $1 \mathrm{C}$ ). We then tested whether the control of NF- $\kappa \mathrm{B}$ via HDAC2 relies on the deacetylase activity of HDAC2. We analyzed how the catalytically

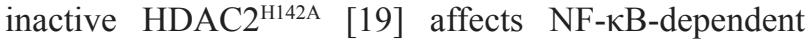
reporter gene expression. Like HDAC2 ${ }^{\mathrm{K} 462 \mathrm{R}}, \mathrm{HDAC} 2^{\mathrm{H} 142 \mathrm{~A}}$ failed to activate the $\mathrm{NF}-\kappa \mathrm{B}$ reporter in RKO (Figure 1C) and HEK293T cells (Supplementary Figure S1B).

Mutation of K462 may also abrogate posttranslational modifications other than sumoylation. Thus, we also tested HDAC2 mutants of the surrounding $\Psi \mathrm{KxE}$ sumoylation-consensus motif (Supplementary Figure S1C). The mutants HDAC2 ${ }^{\mathrm{V} 461 \mathrm{~A}}$ and HDAC2 ${ }^{\mathrm{E} 464 \mathrm{~A}}$, 
which cannot become sumoylated [19], are not able to induce the NF- $\mathrm{BB}$-dependent reporter. In contrast, mutation of the sumoylation-irrelevant $\mathrm{x}$ position $\left(\mathrm{HDAC} 2^{\mathrm{E} 463 \mathrm{~A}}\right)$ retains the ability of HDAC2 to activate $\mathrm{NF}-\kappa \mathrm{B}-\mathrm{dependent}$ luciferase expression (Supplementary Figure S1C, S1D).

\section{HDAC2 regulates unstimulated, endogenous $\mathrm{NF}-\kappa \mathrm{B}-\mathrm{dependent}$ gene expression and apoptosis following genotoxic stress}

The HDAC2-mediated induction of the $\mathrm{NF}-\kappa \mathrm{B}$ luciferase reporter could be a direct effect on the NF- $\kappa B$ pathway or a general regulation of the transcriptional machinery. As shown in Figure 2A, siRNA against p65 completely abolished the HDAC2-dependent activation of the NF- $\kappa \mathrm{B}$ luciferase reporter in RKO cells, illustrating that HDAC2 induction of this reporter functions through p65. Similar results were obtained using siRNA against RelB (Supplementary Figure S2A). Treatment with TNF $\alpha$ induced the luciferase reporter expression regardless if cells were transfected with HDAC2 or HDAC2 ${ }^{\mathrm{K} 462 \mathrm{R}}$ (Supplementary Figure S2B). There was a small but insignificant trend that the NF- $\kappa \mathrm{B}$ luciferase reporter is activated stronger by $\mathrm{TNF} \alpha$ in the presence of HDAC2 compared to $\mathrm{HDAC} 2^{\mathrm{K} 462 \mathrm{R}}$ or control (Supplementary Figure S2B). Thus, the reporter system remains cytokineinducible irrespective of HDAC2 sumoylation.

Our previous results demonstrated that cells stably transfected with HDAC2 and HDAC2 ${ }^{\mathrm{K} 462 \mathrm{R}}$ (RKO
HDAC2-V5 and RKO HDAC2 $2^{\mathrm{K} 462 \mathrm{R}}$-V5, respectively) showed differences in their resistance toward genotoxic stress [19]. Accordingly, we asked whether pro-survival $\mathrm{NF}-\kappa \mathrm{B}$ target genes could be responsible for the protection of cells with wild-type HDAC2. We found a slight upregulation of the anti-apoptotic proteins BCL$\mathrm{X}_{\mathrm{L}}$ and survivin in RKO HDAC2-V5 compared to RKO HDAC2 ${ }^{\mathrm{K} 462 \mathrm{R}}-\mathrm{V} 5$ cells (Figure $2 \mathrm{~B}$ ). However, the levels of numerous other classical NF- $\kappa \mathrm{B}$ target genes were not altered in their expression (data not shown). The levels of NF- $\kappa$ B family members (Figure $2 \mathrm{C}$ ) and of proteins controlling the NF- $\kappa \mathrm{B}$ pathway (Figure 2D) were not different in cells stably reconstructed with HDAC2 or HDAC $2^{\mathrm{K} 462 \mathrm{R}}$. These results disfavor altered levels of these factors as an explanation for the HDAC2-dependent NF$\kappa \mathrm{B}$ signaling activities we reveal here.

Next, we tested whether NF-кB-dependent survival signaling is enhanced by HDAC2 but not by $\mathrm{HDAC} 2^{\mathrm{K} 462 \mathrm{R}}$ in RKO cells. The anthracycline doxorubicin is a genotoxin by virtue of its abilities to intercalate into DNA and to block topoisomerase II $[31,32]$. It is far more toxic to cells expressing sumoylation-deficient HDAC2 [19] and we wanted to find out whether this might be linked to NF- $\kappa \mathrm{B}$ activity in HDAC2-positive RKO cells. Therefore, we added the NF- $\kappa \mathrm{B}$ inhibitor caffeic acid phenethyl ester (CAPE) to RKO HDAC2-V5 and RKO HDAC2 ${ }^{\mathrm{K} 462 \mathrm{R}}-\mathrm{V} 5$ cells; CAPE blocks the DNA binding of NF- $\kappa \mathrm{B}$ proteins [9]. We noted that CAPE enhanced doxorubicin-induced apoptosis rates in RKO HDAC2-V5 and in RKO HDAC2 ${ }^{\mathrm{K} 462 \mathrm{R}}$-V 5 cells (Figure 2E). Moreover, RKO HDAC2-V5 cells are sensitive for CAPE even
A

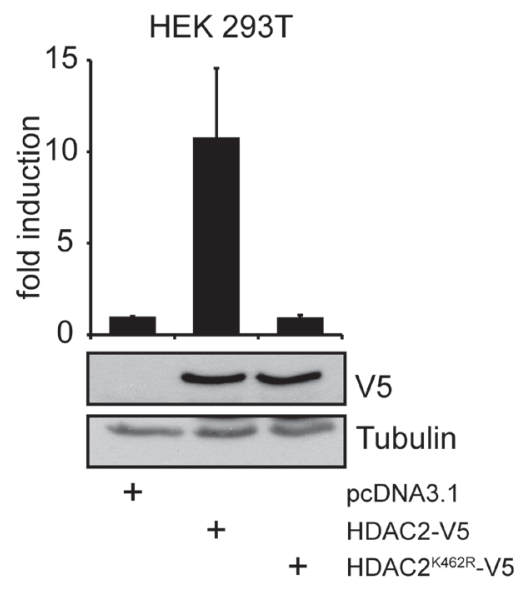

B

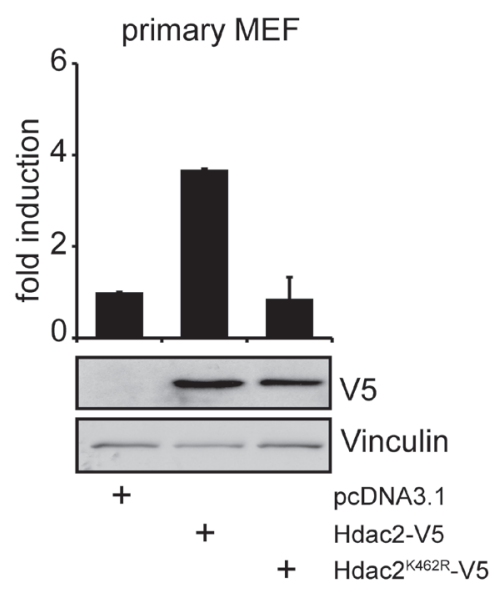

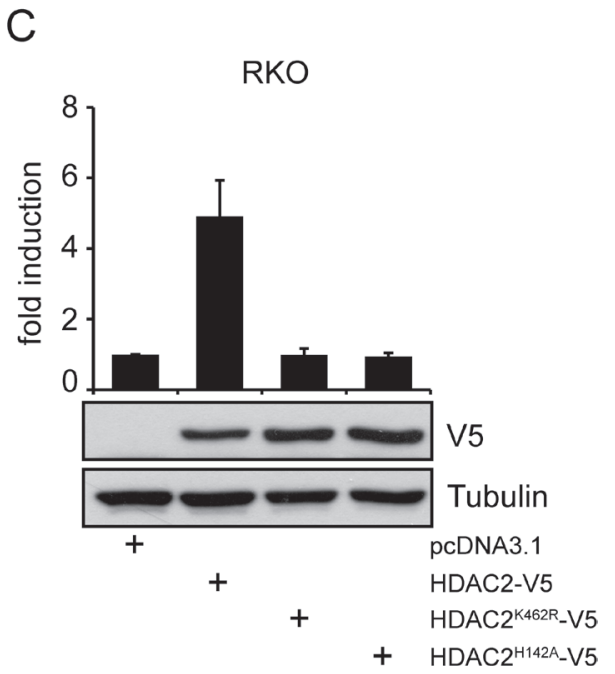

Figure 1: NF-кB-dependent gene expression is regulated in cancer and primary cells by HDAC2 but not by sumoylation deficient HDAC2 ${ }^{\mathrm{K} 462 \mathrm{R}}$. (A) Luciferase assay in HEK293T cells shows induction of 4xкB-Luciferase (Luc) reporter gene when HDAC2, but not when sumoylation deficient $\mathrm{HDAC} 2^{\mathrm{K} 462 \mathrm{R}}$ is expressed. A representative immunoblot (IB) of $\mathrm{n}=10$ independent experiments for transfection efficiency and loading control is shown. (B) Primary MEFs transfected with murine Hdac2-V5 and Hdac2 ${ }^{\mathrm{K} 462 \mathrm{R}}-\mathrm{V} 5$ show induction of a $5 \times 1 \times B-L u c$ reporter only by wild-type Hdac2. Graph is the mean of $n=2$ experiments. (C) HDAC2-negative-RKO cells were transfected as in (A), additionally a catalytically not functional HDAC2 ${ }^{\mathrm{H} 142 \mathrm{~A}}$ is coexpressed, $\mathrm{n}=4$. Graphs show mean \pm s.e.m. fold induction of luciferase intensity after normalization to activity of cotransfected $\beta$-Galactosidase ( $\beta$-Gal), compared to the pcDNA3.1 transfected control. 
without additional doxorubicin treatment (Figure 2E), illustrating that these cells rely on NF- $\kappa \mathrm{B}-d e p e n d e n t$ survival signaling. These data suggest that interfering with $\mathrm{NF}-\kappa \mathrm{B}$ attenuates survival signaling protecting $\mathrm{RKO}$ HDAC2-V5 cells.

Figure 2B shows enhanced survivin expression in RKO HDAC2-V5 cells and we hence investigated whether inhibition of survivin with YM155 is able to sensitize RKO HDAC2-V5 cells to genotoxic stress caused by doxorubicin. YM155 antagonizes survivin, some other NF-кB-regulated signaling molecules, and further pathways [33]. We found that YM155 promotes apoptosis in such cells treated with doxorubicin (Figure $2 \mathrm{~F}$ ). From these data we conclude that the attenuation of $\mathrm{NF}-\kappa \mathrm{B}$ and survivin can increase the sensitivity of RKO cells harboring wild-type HDAC2 to an anthracycline causing DNA damage.

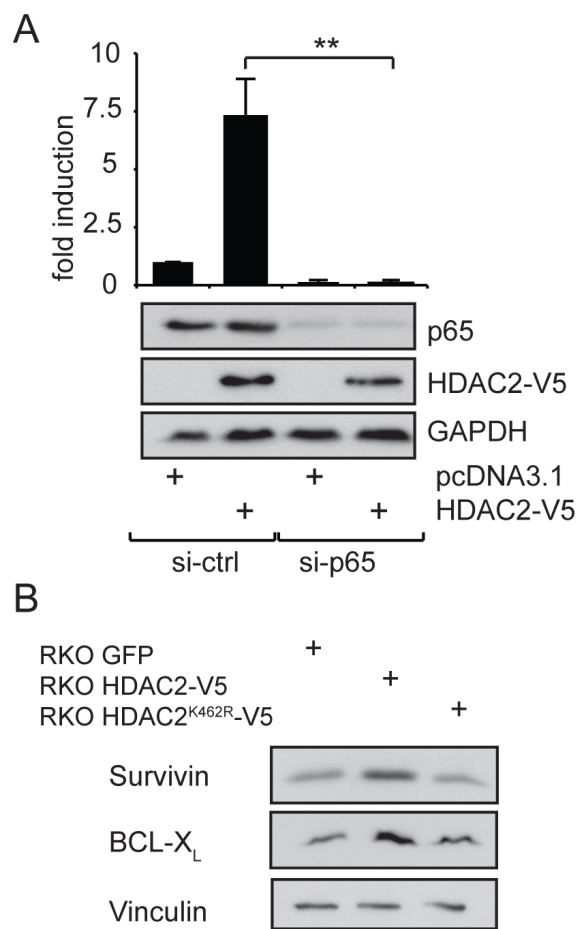

C

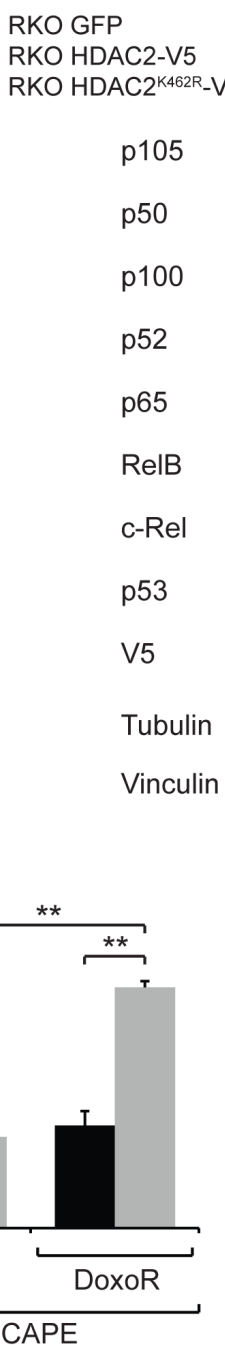

E

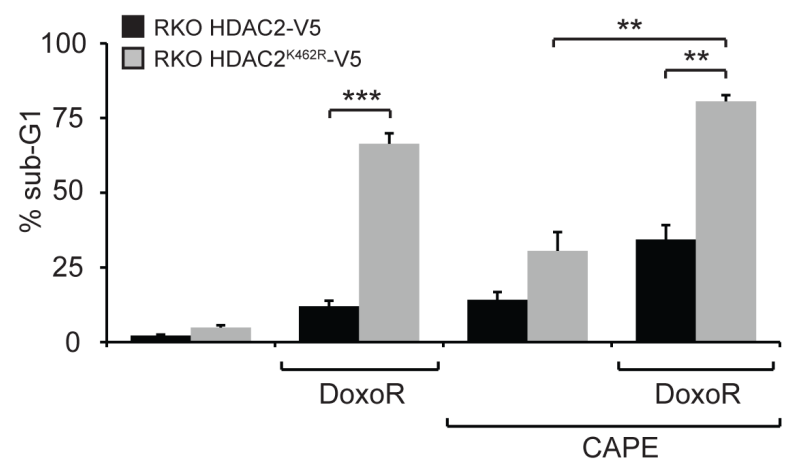

D

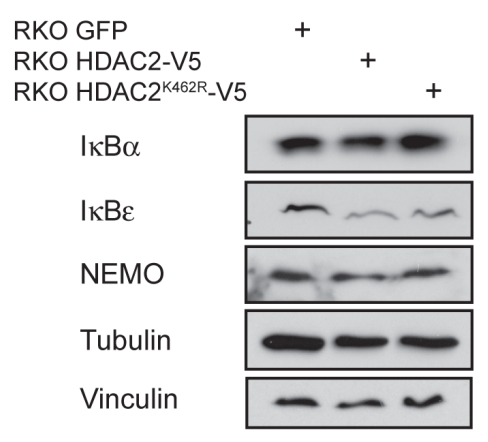

F

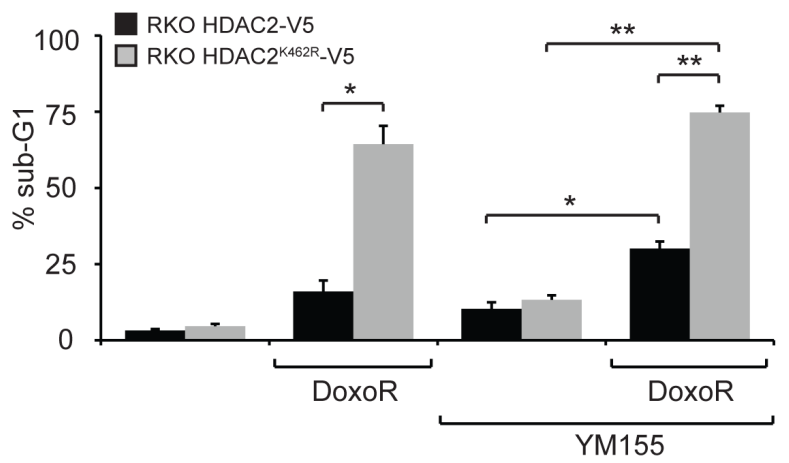

Figure 2: Expression levels of $\mathrm{NF}-\kappa \mathrm{B}$ target genes and influence on genotoxic stress tolerance in a model cell system comparing wild-type HDAC2 and non-sumoylatable HDAC2 ${ }^{\mathrm{K} 462 \mathrm{R}}$. (A) Knockdown of p65 with siRNA confirms that HDAC2 acts directly via NF- $\kappa B$ on the reporter. Here: $n=4 ; * *=p<0.01$. (B) Expression levels of NF- $\kappa B$ target genes survivin and Bcl- $X_{L}$ in stably transfected RKO GFP, RKO HDAC2-V5 and RKO HDAC2 ${ }^{\mathrm{K} 462 \mathrm{R}}-\mathrm{V} 5$. Increased activity of NF- $\mathrm{KB}$ in the presence of HDAC2 results in slightly enhanced expression of the NF- $\mathrm{KB}$ targets survivin and $\mathrm{Bcl}-\mathrm{X}_{\mathrm{L}}$ in cells carrying HDAC2 compared to HDAC2 ${ }^{\mathrm{K} 462 \mathrm{R}}$. (C) Expression of the indicated NF- $\kappa B$ proteins or $(\mathrm{D})$ the indicated NF- $\kappa$ B regulatory proteins is not grossly different between RKO GFP, RKO HDAC2-V5 and $\mathrm{RKO} H \mathrm{HDAC}{ }^{\mathrm{K} 462 \mathrm{R}}-\mathrm{V} 5$ colon cancer cells. (E) Influence on genotoxic stress tolerance in a model cell system comparing wild-type HDAC2 and non-sumoylatable HDAC2 ${ }^{\mathrm{K} 462 \mathrm{R}}$. Apoptosis induction in RKO HDAC2-V5 and HDAC2 ${ }^{\mathrm{K} 462 \mathrm{R}}$-V 5 cells after $24 \mathrm{~h}$ treatment with $1 \mu \mathrm{M}$ Doxorubicin (DoxoR) in combination with $25 \mu \mathrm{M}$ NF- $\kappa \mathrm{B}$ inhibitor caffeic acid phenethyl ester (CAPE). CAPE was added 30 min prior to DoxoR. (F) As in (E), but cells were coincubated with $1 \mu \mathrm{M}$ DoxoR in combination with $100 \mathrm{nM}$ of the survivin suppressant YM155 as indicated. Bar diagrams show mean \pm sem of $\%$ sub-G1 fraction of $n=5(E)$ or $n=3(F)$ experiments, $* *=p<0.01 ; * * *=p<0.001$. 


\section{Induction of NF- $\mathrm{NB}$ activity by HDAC2 depends on p53}

The tumor suppressor p53 has an important impact on NF-kB-dependent gene expression by interaction with NF-кB [9] and via indirect mechanisms $[4,10]$. We therefore tested for a functional contribution of $\mathrm{p} 53$ toward the HDAC2-dependent control of NF- $\mathrm{KB}$. Interestingly, $\mathrm{p} 53$ is an NF- $\mathrm{KB}$ target $[34,35]$ and this should result in higher $p 53$ mRNA levels in cells with enhanced NF$\kappa \mathrm{B}$ activity. Indeed, $p 53 \mathrm{mRNA}$ levels were higher in RKO cells expressing wild-type HDAC2 (Figure 3A). Consistently, protein levels of p53 are higher in these cells (see Brandl et al. 2012 and Figure 2C). Furthermore, after diminishing NF- $\mathrm{KB}$ p 65 by RNAi the expression of $T p 53$ in RKO cells became reduced (Figure 3A). These data point out that TP53 is a p65/HDAC2 target gene in our cell system. We then investigated whether NF-кBdependent transcription induced by HDAC2 relies on the presence of $\mathrm{p} 53$ in NF- $\mathrm{KB}$ transcriptional complexes. As shown in Figure 3B, p53 is recruited to NF- $\mathrm{KB}$ protein complexes which were precipitated in an $\mathrm{ABCD}$ assay by oligonucleotides carrying $\mathrm{\kappa B}$ consensus binding sequences. The interaction is stronger in lysates from RKO cells expressing HDAC2, but not in cells expressing $\mathrm{HDAC} 2^{\mathrm{K} 462 \mathrm{R}}$ or GFP for control (Figure 3B).

Interestingly, the results depicted in Figure 3C further demonstrate that $\mathrm{p} 53$ is necessary for the activation of NF- $\mathrm{kB}$ through HDAC2. The knockdown of p53 with shRNA diminishes the induction of NF- $\mathrm{KB}$ reporter gene expression caused by HDAC2 (Figure 3C). Many p53 functions are dependent on its acetylation and HDAC2 can specifically reduce the acetylation of p53 at K320 [19]. We considered that a p53 molecule mimicking p53 acetylation at K320 (pseudo-acetylated $\mathrm{p} 53^{\mathrm{K} 320 \mathrm{Q}}$ ) may abrogate positive effects of $\mathrm{p} 53$ on NF- $\mathrm{kB}$. To test this, we used the NF-kB-dependent luciferase assay and the reported possibility to activate it through $\mathrm{p} 53$ overexpression [11, 12]. However, reconstitution of p53-negative HCT 116 colon cancer cells with wild-type p53 or p53 $3^{\mathrm{K} 320 \mathrm{Q}}$ similarly activated NF- $\kappa$ B reporter gene expression (Supplementary Figure S3A). This may exclude that $\mathrm{p} 53^{\mathrm{K} 320}$ acetylation has an impact on NF- $\mathrm{kB}$ expression.

\section{Modulation of the nuclear localization of p65 by HDAC2 and by genotoxic stress}

To gain further insights into how HDAC2 controls NF- $\kappa B$-dependent transcription, we investigated whether HDAC2 alters NF- $\mathrm{KB}$ activity through the kinase RSK1, which is necessary for the $\mathrm{p} 53$-dependent gene expression controlled by NF- $\mathrm{kB}$ [12]. Indeed, the knockdown of RSK1 led to a strong decrease of NF- $\kappa B$ reporter gene activity and blunted the stimulating effect of HDAC2 on NF- $\mathrm{KB}$ (Figure 4A). From these observations we conclude that RSK1 is required for the activation of NF- $\mathrm{KB}$ by HDAC2.

Since p53 is nuclear in RKO cells (Supplementary Figure S3B), the interaction between p65 and p53 in HDAC2 reconstituted RKO cells may affect the subcellular localization of p65. Furthermore, RSK1 is also able to influence the subcellular localization of NF$\kappa \mathrm{B}$ p65 [12]. We determined the intracellular distribution of p65 by fluorescence microscopy in HDAC2-negative
A

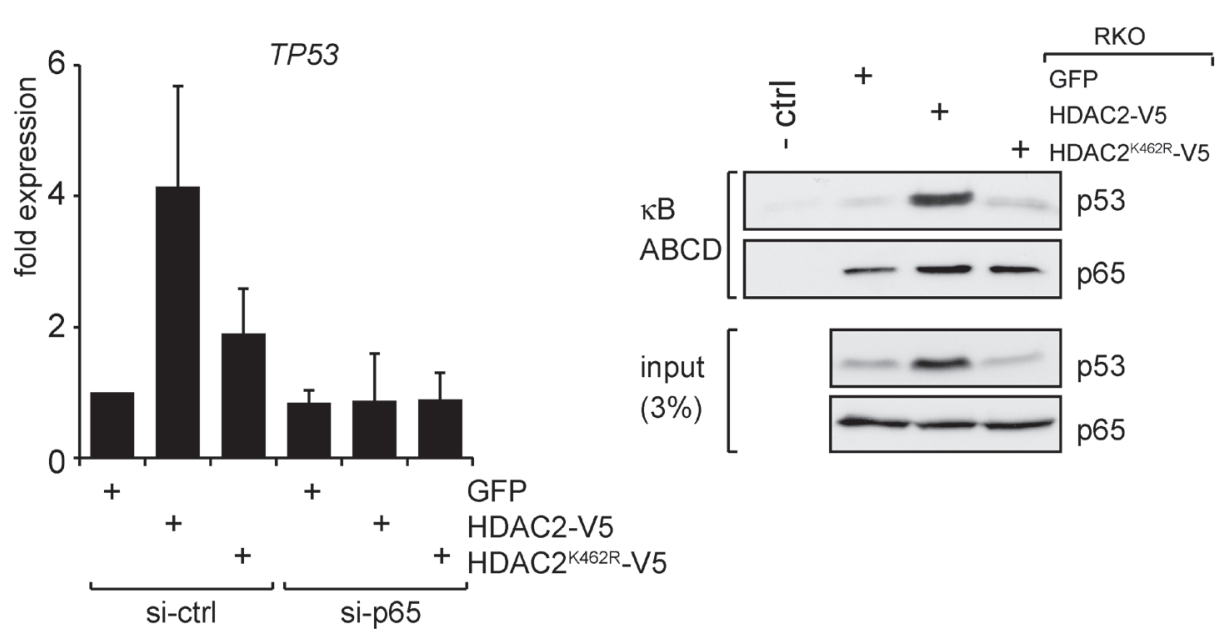

C

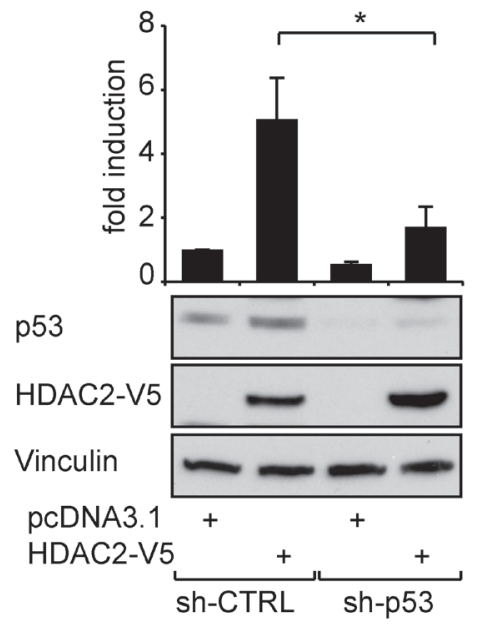

Figure 3: HDAC2 influences NF-кB-dependent TP53 expression and p53 crosstalks with NF- $\mathrm{B}$ to regulate NFKB transcriptional activities. (A) qPCR of TP53 in RKO cells stably transfected as indicated and additional knockdown of p65. Diminishing p65 abrogates enhanced TP53 expression. (B) ABCD assay showing p53 binding to NF-kB complexes using RKO cells stably transfected with HDAC2-V5, HDAC2 ${ }^{\mathrm{K} 462 \mathrm{R}}-\mathrm{V} 5$ or GFP for control. The amount of p53 recruited to $\mathrm{kB}$ consensus sites is dependent on the $\mathrm{HDAC} 2$ status. More $\mathrm{p} 53$ is recruited to NF- $\mathrm{kB}$ when wild-type HDAC2 is present. (C) p53 knockdown attenuates the induction of NF- $\mathrm{kB}$ reporter gene by $\mathrm{HDAC} 2 ; \mathrm{n}=5$. 
RKO cells, RKO HDAC2-V5 and RKO HDAC2 $2^{\mathrm{K} 462 \mathrm{R}}-\mathrm{V} 5$ cells. We additionally transfected the cells with p65-GFP, to monitor p65 via the GFP signal and to increase the pool of $\mathrm{p} 65$. In the presence of HDAC2, a significant portion of p65-GFP is shifted to the nucleus, while RKO and RKO HDAC $2^{\mathrm{K} 462 \mathrm{R}}-\mathrm{V} 5$ cells show a more cytosolic distribution of p65-GFP (Figure 4B). In agreement with these data, it has been found that HDAC2 levels are often elevated in pancreatic cancers and that tumors showing high HDAC2 expression also have increased nuclear p65 levels [36, 37]. Treatment with leptomycin B (LMB) was used to exclude general defects in the nuclear export machinery in RKO cells. As expected, LMB treatment traps p65-GFP to the nucleus regardless of the HDAC2 status of the cells (Figure 4C). Thus, an altered p53 interaction with p65 in cells expressing HDAC2 could explain the increased nuclear localization of p65.

Further, we tested the subcellular distribution of endogenous p65 in RKO HDAC2-V5 and RKO HDAC2 $2^{\mathrm{K} 462 \mathrm{R}}$-V5 cells exposed to genotoxic stress induced by doxorubicin. We had previously reported that doxorubicin decreased the conjugation of SUMO1 to HDAC2 [19] and we therefore asked if p65 translocated to the nucleus equally in the doxorubicin-treated $\mathrm{RKO}$ HDAC2 wild-type/HDAC2 $2^{\mathrm{K} 462 \mathrm{R}}$ cell pair. Indeed, this drug triggered the accumulation of p65 in in both cell types (Figure 4D) suggesting that this process is not hampered by HDAC2.

Doxorubicin only induces NF- $\kappa \mathrm{B}$ target genes in a p53 null background [38], but wild-type p53 is present in RKO cells [19]. Therefore, we used hydroxyurea (HU). This drug causes replicative stress by ribonucleotide reductase inhibition and subsequent dNTP depletion and DNA damage via the breakdown of replication forks [4]. The analysis of cells exposed to HU allowed us to test if the suppression of p53 target genes by HDAC2 [19] and the effect of HDAC2 on NF- $\mathrm{BB}$, which we show here, persist upon activation of the replicative checkpoint with HU. We could successfully stall RKO HDAC2-V5 cells in $\mathrm{S}$ phase (Figure 4E). HU blocks replication fork progression and/or induces DNA damage as seen by an accumulation of $\gamma \mathrm{H} 2 \mathrm{AX}$, and an induction of $\mathrm{p} 53$, which is accompanied by an induction of its target gene BAX. However, HU-induced p53 does not trigger a repression of survivin (Figure 4F). These results suggest that replicative stress can relieve the suppression of p53 activity by wildtype HDAC2, but that this accumulation of p53 also leads to an accumulation of survivin in such cells.

\section{DISCUSSION}

NF- $\kappa \mathrm{B}$-dependent gene expression can be both, positively and negatively affected by HDAC2 [24-26]. Here we show that HDAC2 enhances NF- $\kappa$ B-dependent gene expression in tumor-derived cell lines and in primary cells (Figure $1 \mathrm{~A}-\mathrm{C}$ ). HDAC2 has a typical $\Psi \mathrm{KxE}$ sumoylation consensus motif ( $\mathrm{VK}^{462} \mathrm{EE}$ in HDAC2) in its unstructured C-terminal domain. Mutating K462, V461, or E464 abrogates the posttranslational modification of HDAC2 with SUMO1 [19]. Interestingly, mutants of HDAC2 which are sumoylation-deficient do not show an influence toward NF- $\mathrm{NB}$ activity and neither does a catalytically inactive HDAC2. In order to investigate the influence of HDAC2 on the expression of endogenous $\mathrm{NF}-\kappa \mathrm{B}$ target genes, we used stably transfected RKO cell lines. The expression of NF- $\mathrm{BB}$ family members and proteins controlling the NF- $\kappa \mathrm{B}$ activation pathway is not altered in the cellular models investigated (Figure 2C, 2D), excluding altered regulation of $\mathrm{NF}-\kappa \mathrm{B}$ at this level. In RKO cells stably expressing wild-type HDAC2, numerous classical NF- $\kappa \mathrm{B}$ target genes including $\mathrm{I} \kappa \mathrm{B} \alpha$ are also not altered in their expression levels. In agreement with these data, I $\kappa \mathrm{B} \alpha$ was previously reported to be regulated independently of HDAC2 [39]. However, stimulation of RKO cells with the cytokine TNF $\alpha$ verified that NF$\kappa \mathrm{B}$ signaling evoked by classical IKK/I $\mathrm{B}$ activation is intact in RKO cells expressing HDAC2 or HDAC2 ${ }^{\mathrm{K} 462 \mathrm{R}}$ (Supplementary Figure S2B). Thus, there is no general defect in NF- $\kappa \mathrm{B}$ in RKO cells expressing the HDAC2 sumoylation mutant.

Strikingly, the transcription of the gene coding for p53 was enhanced when HDAC2 was present and this could be abrogated by a p65 knockdown (Figure 3A). TP53 carries an evolutionary conserved consensus $\kappa \mathrm{B}$-binding site [34, 40]. Accordingly, the expression of TP53 is diminished when NF- $\kappa$ B is blocked [34] and recent data show that a knockdown of p65 decreases p53 protein levels [35]. Many mechanisms including post-transcriptional events regulate p53 protein levels. Still, enhanced NF- $\kappa \mathrm{B}$ activity could in part explain our previous observation of enhanced - yet functionally inactive - p53 in cells with HDAC2 [19]. Levels of the anti-apoptotic $\mathrm{NF}-\kappa \mathrm{B}$ target genes $\mathrm{BCL}-\mathrm{X}_{\mathrm{L}}$ and survivin were slightly elevated in cells carrying HDAC2 compared to cells expressing sumoylation-deficient $\mathrm{HDAC}^{\mathrm{K} 462 \mathrm{R}}$ (Figure 2B). Again, other factors could tie into the regulation of both genes. Expression of survivin can be downregulated by active p53 and enhanced survivin levels by HDAC2 might be the result of both, elevated NF- $\kappa B$ activity and p53 inactivation [19]. Consistent with the higher levels of anti-apoptotic protein expression, blocking $\mathrm{NF}-\kappa \mathrm{B}$ activity with CAPE or YM155 led to an increased rate of apoptosis (Figures 2E, 2F). These findings are coherent with previous results, which were collected in cancer cells treated with doxorubicin and inhibitors of NF$\kappa \mathrm{B}$ signaling initiated in the cytosol (reviewed in [38]). The higher sensitivity of colon cancer cells lacking wildtype HDAC2 is also in agreement with the observation that a knockdown of HDAC2 in pancreatic ductal adenocarcinoma (PDAC) has no effect on cell viability but sensitizes PDAC cell lines to etoposide-induced apoptosis [37]. Our novel data show that sumoylation 
A

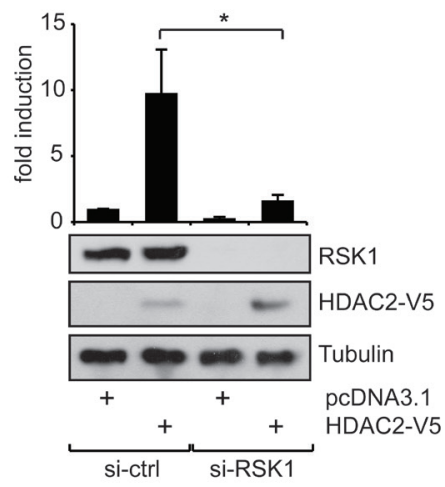

B

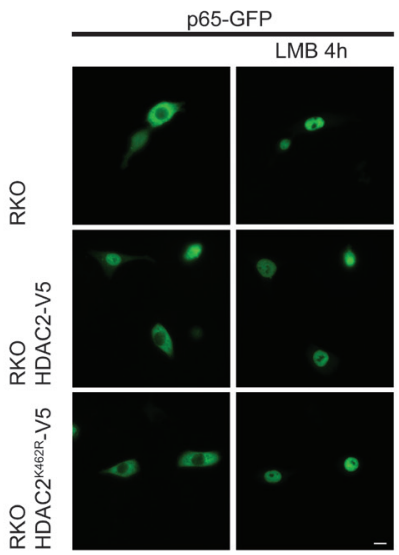

C

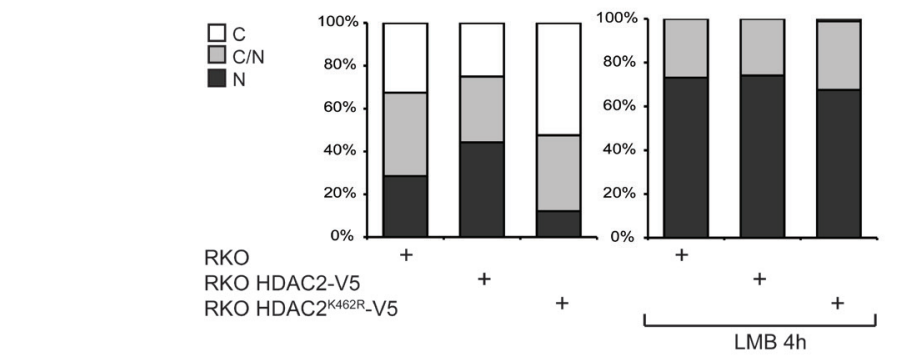

D

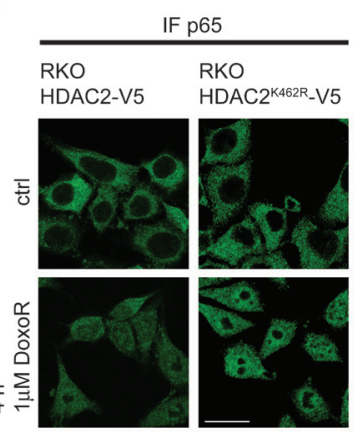

E

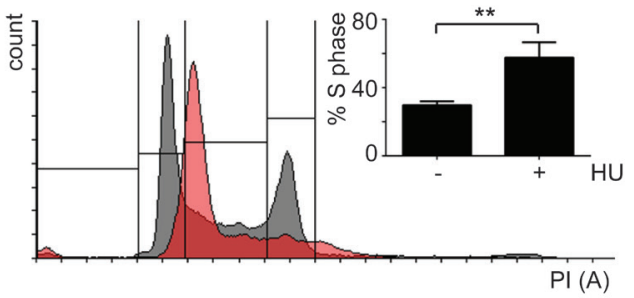

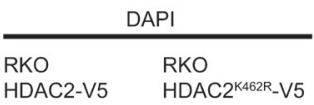
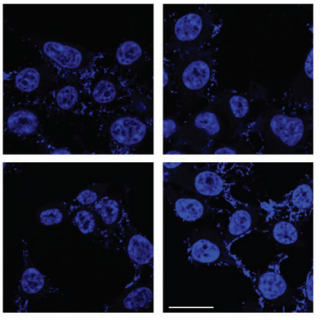

F
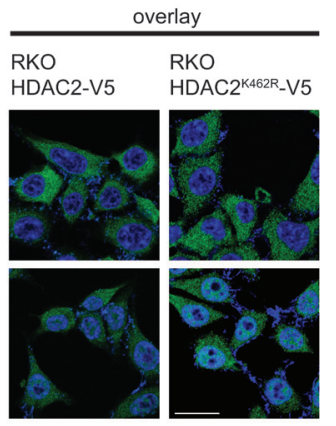

Figure 4: Connection of RSK1 activity and subcellular localization of p65 toward HDAC2 induction of NF- $\mathrm{KB}$. (A) Knockdown of RSK1 diminishes HDAC2-caused NF- $\kappa$ B reporter gene induction; $n=4$. (B) Representative image of RKO, RKO HDAC2-V5 and RKO HDAC2 ${ }^{\mathrm{K} 462 \mathrm{R}_{-} \mathrm{V} 5}$ cells transfected with p65-GFP, showing enhanced nuclear localization of p65 in RKO HDAC2-V5 cells. Inhibition of nuclear export by Leptomycin B (LMB) leads to nuclear retention of p65-GFP regardless of HDAC2 status. (C) Quantification of (D) counting at least 100 cells in two independent experiments. $\mathrm{C}$ and $\mathrm{N}$ depict predominantly ( $>80 \%)$ cytosolic or nuclear localization of p65-GFP, respectively, $\mathrm{C} / \mathrm{N}=$ intermediate distribution of p65-GFP. (D) RKO HDAC2-V5 and RKO HDAC2 ${ }^{\mathrm{K} 462 \mathrm{R}}$-V5 cells were treated with $1 \mu \mathrm{M}$ doxorubicin (DoxoR) for $4 \mathrm{~h}$ or left untreated for control. Fixed cells were stained with antibodies against p65 and visualized with $\mathrm{Cy} 2$ or $\mathrm{Cy} 3$ labeled secondary antibody. DNA was stained by mounting medium containing DAPI. Brightness levels for p65 were adjusted for RKO HDAC2-V5 ctrl (45), RKO HDAC2 ${ }^{\mathrm{K} 462 \mathrm{R}}-\mathrm{V} 5$ ctrl (35) and DoxoR (35, all from original 50). Brightness for DAPI was adjusted for RKO HDAC2 ${ }^{\mathrm{K} 462 \mathrm{R}}-\mathrm{V} 5$ cells DoxoR (to 45 from original 50). Scale bar $=20 \mu \mathrm{m}$. (E) RKO HDAC2-V5 cells were treated with $1.5 \mathrm{mM}$ Hydroxyurea (HU) for $24 \mathrm{~h}$ and cell cycle distribution was analyzed by PI staining. The bar diagram shows the amount of cells in $\mathrm{S}$-Phase of $\mathrm{n}=5$ experiments; $\pm \mathrm{sem}, * *=\mathrm{p}<0,01$. A histogram for one representative experiment shows cell cycle profile of control cells in black and of HU treated cells in red. (F) RKO HDAC2-V5 cells were treated with $1.5 \mathrm{mM} \mathrm{HU}$ for 2, 6 and $24 \mathrm{~h}$ or left untreated for control. Levels of the indicated proteins were analyzed by Western blot. 
of HDAC2 provides a survival benefit compared to nonsumoylatable HDAC2 $2^{\mathrm{K} 462 \mathrm{R}}$ and that $\mathrm{NF}-\kappa \mathrm{B}$ contributes to this phenotype. Replicative stress caused by dNTP depletion blocks replication fork progression. This also liberates p53's activating functions on transcription, but not its repressive effects on survivin (Figure 4F). Here, a $\mathrm{p} 53 / \mathrm{NF}-\kappa \mathrm{B}$ crosstalk [9] seems to operates and to exert a dominant effect on survivin expression.

Sumoylation often alters the interactome of the modified proteins [41]. However, we did not observe that interaction of p 65 with $\mathrm{HDAC} 2$ or that the acetylation of p $65^{\mathrm{K} 310}$ was dependent on the sumoylation of HDAC2 (data not shown). These findings are consistent with the literature that speaks against the deacetylation of $\mathrm{p} 65$ by HDAC2; HDAC1 and HDAC3 are though commonly found to counteract p65 acetylation [42-44]. Moreover, HDAC2 and HDAC3 interact with acetylated p65, but only HDAC3 is able to deacetylate p65 [43]. In murine neuronal models, p65 acetylation and downstream effects were not affected by either HDAC1 or HDAC2 alone; only when both were disrupted the acetylation of p65 was augmented [44]. Other studies equally suggest that HDAC2 cannot directly bind p65 [25], and the interaction between HDAC2 and $\mathrm{NF}-\kappa \mathrm{B}$ may require very specific conditions in vivo. It is conceivable that inconsistent results reported for the interaction between HDAC2 and $\mathrm{NF}-\kappa \mathrm{B}$ [24-27], rely on differences in the cellular p53 status, HDAC1/HDAC2 heterodimerization, or altered RSK1 activity. However, deacetylation of p53 or p65 unlikely explains the stimulating effect of HDAC2 on NF$\kappa \mathrm{B}$ in our model system.

Crosstalk between p53 and NF- $\kappa \mathrm{B}$ family members contributes to oncogenesis, metastasis, and immune functions [9, 11, 28, 29]. A recent study shows that $\mathrm{NF}-\kappa \mathrm{B}$ transcriptional activity in breast cancer cells depends on their p53 mutational status [38]. Only cells with mutated p53 showed upregulation of NF- $\kappa B$ target genes after treatment with the chemotherapeutic

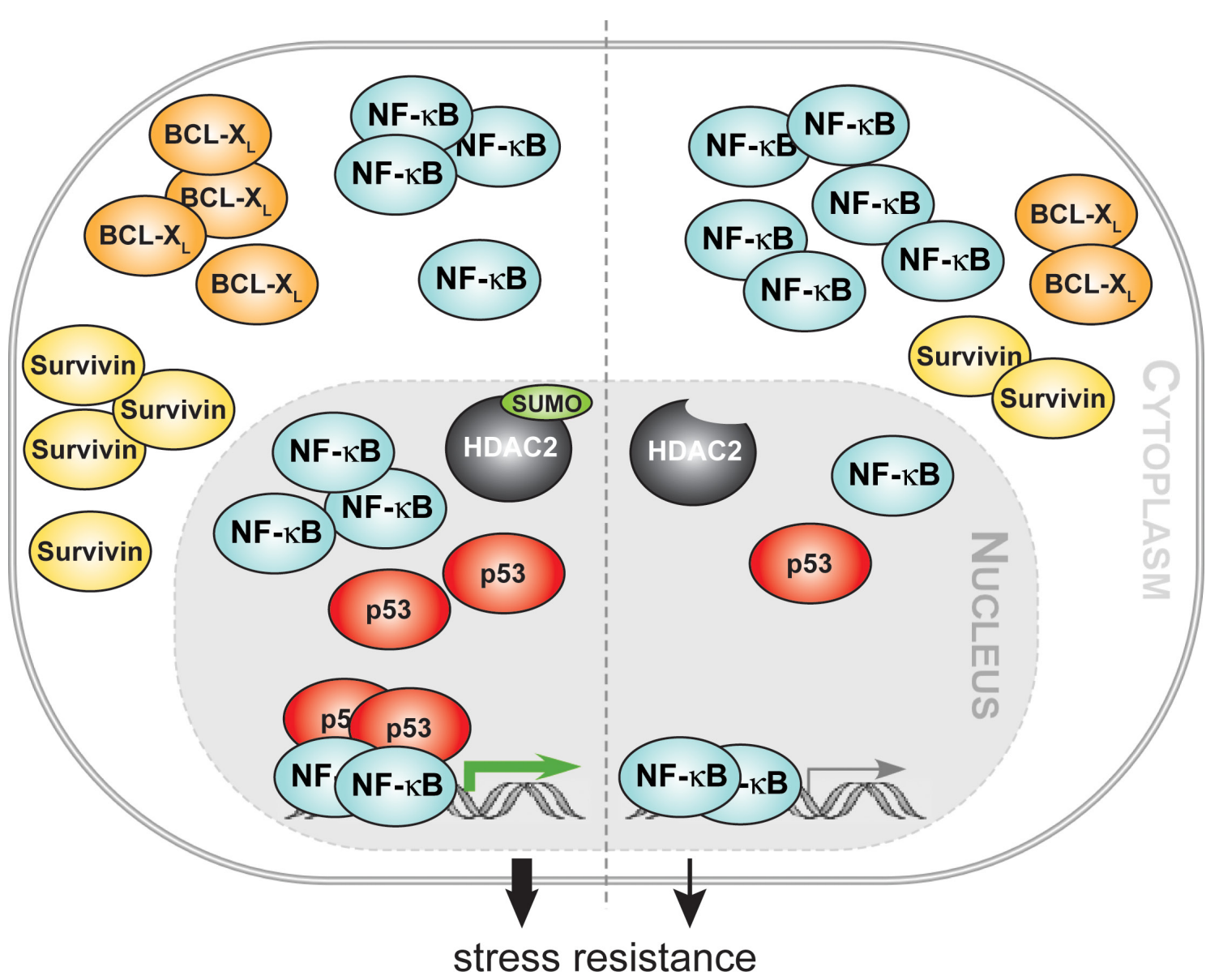

Figure 5: HDAC2 sumoylation integrates NF-кB signaling. Our work reveals that the epigenetic regulator histone deacetylase 2 (HDAC2) can activate NF-kB-dependent gene expression in human cancer cells and in murine embryonic fibroblasts. We show that the posttranslational modification of HDAC2 with the small ubiquitin-related modifier (SUMO) integrates NF- $\mathrm{KB}$ p65 and the tumor suppressor $\mathrm{p} 53$. In the absence of HDAC2 sumoylation the activation of NF- $\mathrm{KB}$ by HDAC2 is strongly diminished. Our data further suggest that enhanced recruitment of p53 to NF- $\mathrm{BB}$ p 65 bound to DNA and an increased nuclear accumulation of p65 are causal for an augmented NF- $\mathrm{B}$-dependent anti-apoptotic gene expression in cells expressing wild-type HDAC2. Additionally, we demonstrate that HDAC2, but not its sumoylation-deficient variant, increases the resistance of colon cancer cells toward genotoxic stress. These findings suggest that the HDAC2-NF- $\mathrm{BB}$ signaling node we report in our manuscript contributes to tumorigenesis and chemoresistance. 
doxorubicin. However, the set of upregulated genes was varying between different tumor cells [38]. Our results extend the findings by Dalmases and colleagues by showing that sumoylated HDAC2, which also specifically causes a functional deficiency in $\mathrm{p} 53$, promotes NF$\kappa \mathrm{B}$-dependent gene expression in colon cancer cells. Moreover, a prolonged NF- $\kappa \mathrm{B}$ activity is also observed when $\mathrm{p} 53$ is mutated in colon cancers [29] and an NF- $\mathrm{KB}$ -dependent inflammatory response critically contributes to tumorigenesis [45]. Remarkably, previous data showed that inhibiting the IKK complex blocks the doxorubicininduced nuclear accumulation of p65 (reviewed in [38]). We demonstrate that the control of NF- $\mathrm{KB}$ p65 by doxorubicin and by the cytokine TNF $\alpha$ (Figures 4D and $\mathrm{S} 2 \mathrm{~B}$ ) is independent of HDAC2 sumoylation and dominant over HDAC2-dependent effects. The control of NF- $\mathrm{KB}$ by HDAC2 requires $\mathrm{p} 53$ and RSK 1 and rather seems to be a nuclear event that is likely independent of IKK.

RSK1 has been described to be an important factor in coordinating the p53 crosstalk in situations when NF$\kappa \mathrm{B}$ is not activated by classical stimuli [12]. Accordingly, knockdown of either $\mathrm{p} 53$ or RSK 1 in our setting abrogates the effect of HDAC2 towards NF- $\mathrm{KB}$ (Figures $3 \mathrm{C}$ and $4 \mathrm{~A}$ ). Additionally the presence of $\mathrm{HDAC} 2$ results in enhanced recruitment of p53 to NF- $\kappa B$ transcriptional complexes (Figure 3B). This cross-signaling between $\mathrm{p} 53$ and NF$\kappa \mathrm{B}$ proteins gives further insight in molecular mechanisms regulating tumorigenesis and might be a point of action for pharmacological intervention $[9,28,29,46]$. In sum, our data show that HDAC2 sumoylation is important for $\mathrm{NF}-\kappa \mathrm{B}-$ dependent gene expression and for the resistance of cell against stress (Figure 5). Hence, monitoring the expression of HDAC2 and its sumoylation status could be of prognostic value and HDAC2 appear as a promising target for therapeutic intervention strategies.

\section{MATERIAL AND METHODS}

\section{Cell culture, chemicals, and generation of mouse embryonic fibroblasts}

HEK 293T, HCT 116 p53-- cells [47], RKO cells lacking HDAC2 [48], RKO cell lines stably transfected with HDAC2 (wild type or HDAC ${ }^{\mathrm{K} 462 \mathrm{R}}$ ) and GFP [19], and mouse embryonic fibroblast (MEF) cell lines were cultivated at $37^{\circ} \mathrm{C}$ and $5 \% \mathrm{CO}_{2}$ in Dulbecco's modified Eagle's medium (DMEM) containing 2\% L-glutamine (PAA; Cölbe, Germany) + 10\% FCS (Sigma-Aldrich). Primary MEFs were isolated from $13.5 \mathrm{dpc}$ wild type (wt) and $\mathrm{Hdac}^{-/}$embryos as described [49]. Primary MEFs were frozen at passage 1 and used for experiments up to passage 6 .

D-Luciferin potassium salt was purchased from
Biomol (Hamburg, Germany), doxorubicin (DoxoR) and caffeic acid phenethyl ester (CAPE) from Enzo (Lörrach, Germany), TNF $\alpha$ from ReliaTech (Wolfenbüttel, Germany), N-ethylmaleimide (NEM), Leptomycin B, and YM155 from Selleckchem (Munich, Germany). All other chemicals were purchased from Carl Roth (Karlsruhe, Germany).

\section{Transfections, luciferase assays, and plasmids}

Plasmids encoding wild-type human HDAC2, mutants derived thereof, and pSV40- $\beta$-GAL4 [19], pSUPER-p53 and -ctrl [50], 3xкB-Luc [51] were described previously. $4 \times \kappa \mathrm{x}-$ and $5 \times \mathrm{x} \mathrm{B}-\mathrm{Luc}$ were generated from $3 \times \kappa$ B-Luc and kindly provided by J. Schmid (Vienna, Austria). A construct expressing V5-tagged murine Hdac2 was generated by TOPO ${ }^{\circledR}$-cloning in pcDNA3.1 vector backbone (Life Technologies). Hdac2 ${ }^{\mathrm{K} 462 \mathrm{R}}$-V5 was derived thereof by QuickChange Site-Directed Mutagenesis (Agilent, Frankfurt/Main, Germany). To generate p65GFP, the p65 coding sequence was amplified from cDNA obtained from a human head and neck tumor as described [52], inserted into the $\mathrm{pF} 25$ expression vector using NheI restriction sites and verified by sequencing as described $[53,54]$. siRNA pools targeting p65 and HDAC2 were purchased from Santa Cruz, RSK1 (RPS6KA1) from Thermo and RelB siRNA was published previously [55].

HEK 293T, HCT- 116 p53-- and all RKO cells were transfected with Lipofectamine ${ }^{\mathrm{TM}} 2000$ (Life Technologies, Darmstadt, Germany) according to the manufacturer's protocol. Transfections for luciferase assays were performed in 24-well plates in triplicate. $0.1 \mu \mathrm{g} \mathrm{pSV} 40-\beta$ GAL, $0.3 \mu \mathrm{g}$ luciferase reporter construct $(3 \mathrm{x} / 4 \mathrm{x} / 5 \mathrm{x}-\mathrm{\kappa B}-$ Luc) and $0.4 \mu \mathrm{g}$ HDAC2 (HDAC2-V5, HDAC2 ${ }^{\mathrm{K} 462 \mathrm{R}}$-V5, HDAC2 ${ }^{\mathrm{H} 142 \mathrm{~A}}-\mathrm{V} 5$ ) were used per well. In p53 knockdown experiments, $0.1 \mu \mathrm{g}$ sh-p53 (pSUPER-p53) and $0.3 \mu \mathrm{g}$ HDAC2 or empty vector were used. In experiments with siRNA knockdown 20 pmol siRNA were cotransfected with a total of $0.4 \mu \mathrm{g}$ plasmids $(0.05 \mu \mathrm{g}$ pSV40- $\beta$-GAL, $0.05 \mu \mathrm{g} \kappa \mathrm{B}-\mathrm{Luc}, 0.3 \mu \mathrm{g}$ HDAC2). Primary MEFs were transfected with Attractene (Qiagen, Cologne, Germany) according to the manufacturer's protocol $(0.2 \mu \mathrm{g} \mathrm{pSV} 40$ $\beta$-GAL, $0.3 \mu \mathrm{g} 5 \mathrm{x}-\kappa \mathrm{B}-\mathrm{Luc}$, and $0.5 \mu \mathrm{g}$ HDAC2 plasmids). For controls, empty vector (pcDNA3.1), sh-ctrl (pSUPERsh-scrambled) and siRNA-ctrl were used. Cells were lysed in luciferase harvest buffer (37.5 mM Tris- $\mathrm{HCl} \mathrm{pH} 8.0$, $12.5 \mathrm{mM}$ 2-(N-Morpholino)ethanesulfonic acid (MES), $10 \%$ glycerol, $0.1 \%$ Triton-X 100, 1 mM DTT, PIC) $48 \mathrm{~h}$ after transfection. The luciferase reporter activity was normalized to the activity of the cotransfected $\beta$-galactosidase reporter. 


\section{ABCD assays, Western blotting, antibodies}

For $\mathrm{ABCD}$ assays cells were seeded in $10 \mathrm{~cm}$ dishes, harvested after $24 \mathrm{~h}$ and lysed in NETN buffer $(150 \mathrm{mM} \mathrm{NaCl}, 20 \mathrm{mM}$ Tris/HCl pH 7.4, 0.5\% NP-40, $10 \%$ glycerol, 1 mM EDTA, 10 mM NEM, 1 mM PMSF, protease inhibitor cocktail [PIC; end concentrations $4 \mu \mathrm{g} / \mathrm{ml}$ antipain, 20 units $/ \mathrm{ml}$ aprotinin, $0.2 \mathrm{mg} / \mathrm{ml}$ benzamidine, $2 \mu \mathrm{g} / \mathrm{ml}$ leupeptine]). Oligonucleotides with a NF- $\kappa$ B consensus site (sense oligo: bio-5'-GGAA TTTCCGGGAATTTCCGGGAATTTCCGGGAATTTC CC) [9] were used to pull down protein complexes and then analyzed by Western Blot as described $[19,56]$. $300 \mu \mathrm{l}$ lysate was incubated together with biotinylated oligonucleotides for $30 \mathrm{~min}$ on ice. For pull down of biotinylated oligonucleotides together with bound proteins streptavidin beads were added to the lysates and put on a rotating wheel for $1 \mathrm{~h}$. As negative control, biotinylated oligonucleotides with a scrambled binding site were incubated with a combination of all lysates used. Bound proteins were eluted from the beads with $2 x$ Laemmli buffer and analyzed by western blotting.

SDS-PAGE and immunoblot were performed as described [57]. Equal loading was controlled with housekeeping proteins. When reprobes were not feasible, same protein amounts from cell lysate were loaded on separate gels to perform parallel IBs. Antibodies used are: mouse $\alpha$-BAX (2D2), rabbit $\alpha$-Bcl2, rabbit $\alpha$-c-Rel $(\mathrm{N}-466)$, rabbit $\alpha$-HDAC2 (H-54), mouse $\alpha$-HSP90 (F-

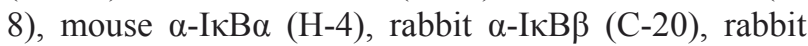
$\alpha$-IкB $\varepsilon$, rabbit $\alpha$-MCL1 (S-19), rabbit $\alpha$-mSIN3A (K$20)$, rabbit $\alpha$-NEMO (FL-419), rabbit $\alpha$-p50 (H-119), mouse $\alpha$-p53 (DO-1), mouse $\alpha$-p65 (F-6), rabbit $\alpha$-p65 (C-20), rabbit $\alpha$-RelB (H-200), rabbit $\alpha$-RSK1 (C-21) (all Santa Cruz); mouse $\alpha$-Bcl-x (BD Pharmingen), mouse $\alpha-\gamma$ H2AX (pS139) (Millipore), mouse $\alpha$-p52 (Upstate), rabbit $\alpha$-survivin (Novus), mouse $\alpha$-alpha-Tubulin (SigmaAldrich), mouse $\alpha$-V5 (Life Technologies). Secondary antibodies goat $\alpha$-rabbit and goat $\alpha$-mouse are from Pierce/ Thermo.

\section{qPCR}

RNA was isolated with RNeasy Kit (Qiagen) and transcribed into cDNA with RevertAid cDNA Synthesis Kit (Thermo). RT-qPCR with primers for TP53 (fwd: GCCCCCAGGGAGCACTA; rev: GGGAGAGGAGCTGGTGTTG) [58] and housekeeping genes RPL13A and HMBS [19] was carried out as described [57].

\section{Fluorescence microscopy and flow cytometry}

RKO, RKO HDAC2-V5 and RKO HDAC2 $2^{\mathrm{K} 462 \mathrm{R}}$-V5 cells were transiently transfected with p65-GFP as described above. After $24 \mathrm{~h}$, protein localization was analyzed in live cells with an AxioVert100 fluorescent microscope (Carl Zeiss, Jena, Germany). Alternatively, cells were incubated with $10 \mathrm{nM}$ leptomycin B (LMB) 4 $\mathrm{h}$ before analysis. To determine the average intracellular localization of p65-GFP, at least 100 fluorescent cells were examined in two independent experiments. The number of cells exhibiting cytoplasmic $(\mathrm{C}$; cytoplasmic signal $>80 \%$ of the total cellular signal), cytoplasmic and nuclear $(\mathrm{C} / \mathrm{N})$ or nuclear $(\mathrm{N}$; nuclear signal $>80 \%$ of the total cellular signal) fluorescence was visually inspected and counted. For staining of endogenous p53 mouse $\alpha$-p 53 (DO-1) was used as described [19]. Images were captured using a digital AxioCam CCD camera with the AxioVision Software (Carl Zeiss).

For visualization of endogenous p65 in RKO

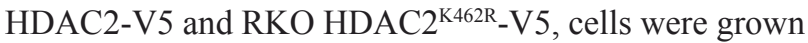
on cover slides and treated as indicated. After treatment, cells were fixed with methanol, incubated with primary mouse $\alpha$-p65 (diluted 1:50) or rabbit $\alpha$-p65 (1:100) antibodies and secondary $\alpha$-mouse antibodies coupled to Cy2 (1:400) or $\alpha$-rabbit antibodies coupled to Cy3 (1:400), respectively (Jackson Immunoresearch, West Grove, PA, USA). DNA staining was carried out by Prolong Gold Antifade mounting medium with DAPI (Invitrogen, Carlsbad, USA). Images were acquired with a Zeiss LSM 710 laser scanning confocal microscope (Carl Zeiss, Jena, Germany). Brightness levels were adjusted as indicated.

Flow cytometry analysis to determine cell cycle distribution by propidium iodide staining was performed as described [19].

\section{Statistical analysis}

Graphs show means of independent experiments \pm standard errors (s.e.m.) if not indicated otherwise in the figure legends. Two-tailed unpaired Student's t-test was used to analyze differences between two groups of samples. Significance was set at $\mathrm{p}<0.05$ if not indicated otherwise in the figure legend.

\section{ACKNOWLEDGMENTS}

This work was supported by Deutsche Krebshilfe (grant 110909; to OHK/GS) and Wilhelm-Sander Stiftung (grant 2010.078.2; to OHK). We thank JA Schmid for kind gift of the $4 \mathrm{x}$ - and $5 \mathrm{x \kappa B}$-Luc constructs, C Imbriano for Flag-p53 plamids, R Bernards and R Agami for shRNA against p53, B Vogelstein for HCT $116 \mathrm{p} 53^{-/}$and M Esteller for HDAC2-negative RKO cells, respectively. We thank S Reichardt and G Greiner for excellent technical 
assistance and F Melchior for fruitful discussion.

\section{CONFLICTS OF INTEREST}

The authors declare no conflict of interest.

\section{Editorial note}

This paper has been accepted based in part on peerreview conducted by another journal and the authors' response and revisions as well as expedited peer-review in Oncotarget.

\section{REFERENCES}

1. Oeckinghaus A, Hayden MS, Ghosh S. Crosstalk in NFkappaB signaling pathways. Nature immunology. 2011; 12: 695-708

2. Hayden MS, Ghosh S. NF-kappaB, the first quarter-century: remarkable progress and outstanding questions. Genes \& development. 2012; 26: 203-234.

3. Staudt LM. Oncogenic activation of NF-kappaB. Cold Spring Harbor perspectives in biology. 2010; 2: a000109.

4. Schneider G, Krämer $\mathrm{OH}$. NFkappaB/p53 crosstalk-a promising new therapeutic target. Biochim Biophys Acta. 2011; 1815: 90-103.

5. McCool KW, Miyamoto S. DNA damage-dependent NFkappaB activation: NEMO turns nuclear signaling inside out. Immunological reviews. 2012; 246: 311-326.

6. Moreno R, Sobotzik JM, Schultz C, Schmitz ML. Specification of the NF-kappaB transcriptional response by p65 phosphorylation and TNF-induced nuclear translocation of IKK epsilon. Nucleic acids research. 2010; 38: 60296044.

7. Roos WP, Kaina B. DNA damage-induced cell death: from specific DNA lesions to the DNA damage response and apoptosis. Cancer Lett. 2013; 332: 237-248.

8. Wu ZH, Wong ET, Shi Y, Niu J, Chen Z, Miyamoto S, Tergaonkar V. ATM- and NEMO-dependent ELKS ubiquitination coordinates TAK1-mediated IKK activation in response to genotoxic stress. Molecular cell. 2010; 40: 75-86.

9. Schneider G, Henrich A, Greiner G, Wolf V, Lovas A, Wieczorek M, Wagner T, Reichardt S, von Werder A, Schmid RM, Weih F, Heinzel T, Saur D, Krämer OH. Cross talk between stimulated NF-kappaB and the tumor suppressor p53. Oncogene. 2010; 29: 2795-2806.

10. Johnson RF, Perkins ND. Nuclear factor-kappaB, p53, and mitochondria: regulation of cellular metabolism and the Warburg effect. Trends in biochemical sciences. 2012; 37: 317-324.

11. Ryan KM, Ernst MK, Rice NR, Vousden KH. Role of NFkappaB in p53-mediated programmed cell death. Nature.
2000; 404: 892-897.

12. Bohuslav J, Chen LF, Kwon H, Mu Y, Greene WC. p53 induces NF-kappaB activation by an IkappaB kinaseindependent mechanism involving phosphorylation of p65 by ribosomal S6 kinase 1. The Journal of biological chemistry. 2004; 279: 26115-26125.

13. Frank AK, Leu JI, Zhou Y, Devarajan K, Nedelko T, Klein-Szanto A, Hollstein M, Murphy ME. The codon 72 polymorphism of p53 regulates interaction with NF-\{kappa $\}$ B and transactivation of genes involved in immunity and inflammation. Molecular and cellular biology. 2011; 31: 1201-1213.

14. Yang XJ, Seto E. The Rpd3/Hda1 family of lysine deacetylases: from bacteria and yeast to mice and men. Nature reviews. Molecular cell biology. 2008; 9: 206-218.

15. Kelly RD, Cowley SM. The physiological roles of histone deacetylase (HDAC) 1 and 2: complex co-stars with multiple leading parts. Biochemical Society transactions. 2013; 41: 741-749.

16. Spange S, Wagner T, Heinzel T, Krämer $\mathrm{OH}$. Acetylation of non-histone proteins modulates cellular signalling at multiple levels. Int J Biochem Cell Biol. 2009; 41: 185-198.

17. Brandl A, Heinzel T, Krämer OH. Histone deacetylases: salesmen and customers in the post-translational modification market. Biology of the cell / under the auspices of the European Cell Biology Organization. 2009; 101: 193205.

18. Ouyang J, Gill G. SUMO engages multiple corepressors to regulate chromatin structure and transcription. Epigenetics : official journal of the DNA Methylation Society. 2009; 4: 440-444.

19. Brandl A, Wagner T, Uhlig KM, Knauer SK, Stauber RH, Melchior F, Schneider G, Heinzel T, Krämer OH. Dynamically regulated sumoylation of HDAC2 controls p53 deacetylation and restricts apoptosis following genotoxic stress. J Mol Cell Biol. 2012; 4: 284-293.

20. Citro S, Jaffray E, Hay RT, Seiser C, Chiocca S. A role for paralog-specific sumoylation in histone deacetylase 1 stability. J Mol Cell Biol. 2013; 5: 416-427.

21. Hickey CM, Wilson NR, Hochstrasser M. Function and regulation of SUMO proteases. Nature reviews. Molecular cell biology. 2012; 13: 755-766.

22. Geiss-Friedlander R, Melchior F. Concepts in sumoylation: a decade on. Nature reviews. Molecular cell biology. 2007; 8: 947-956.

23. Wagner $\mathrm{T}$, Brand $\mathrm{P}$, Heinzel $\mathrm{T}$, Krämer $\mathrm{OH}$. Histone deacetylase 2 controls p53 and is a critical factor in tumorigenesis. Biochimica et biophysica acta. 2014; 1846: 524-538.

24. Yu Z, Zhang W, Kone BC. Histone deacetylases augment cytokine induction of the iNOS gene. Journal of the American Society of Nephrology : JASN. 2002; 13: 20092017.

25. Ashburner BP, Westerheide SD, Baldwin AS, Jr. The p65 
(RelA) subunit of NF-kappaB interacts with the histone deacetylase (HDAC) corepressors HDAC1 and HDAC2 to negatively regulate gene expression. Molecular and cellular biology. 2001; 21: 7065-7077.

26. Kaler P, Sasazuki T, Shirasawa S, Augenlicht L, Klampfer L. HDAC2 deficiency sensitizes colon cancer cells to TNFalpha-induced apoptosis through inhibition of NFkappaB activity. Experimental cell research. 2008; 314: 1507-1518.

27. Ito K, Jazrawi E, Cosio B, Barnes PJ, Adcock IM. p65activated histone acetyltransferase activity is repressed by glucocorticoids: mifepristone fails to recruit HDAC2 to the p65-HAT complex. The Journal of biological chemistry. 2001; 276: 30208-30215.

28. Johnson RF, Witzel, II, Perkins ND. p53-dependent regulation of mitochondrial energy production by the RelA subunit of NF-kappaB. Cancer research. 2011; 71: 55885597.

29. Cooks T, Pateras IS, Tarcic O, Solomon H, Schetter AJ, Wilder S, Lozano G, Pikarsky E, Forshew T, Rozenfeld N, Harpaz N, Itzkowitz S, Harris CC, Rotter V, Gorgoulis VG, Oren M. Mutant p53 Prolongs NF-kappaB Activation and Promotes Chronic Inflammation and InflammationAssociated Colorectal Cancer. Cancer cell. 2013; 23: 634646.

30. Ropero S, Ballestar E, Alaminos M, Arango D, Schwartz S, Jr., Esteller M. Transforming pathways unleashed by a HDAC2 mutation in human cancer. Oncogene. 2008; 27 : 4008-4012.

31. Pommier Y, Leo E, Zhang H, Marchand C. DNA topoisomerases and their poisoning by anticancer and antibacterial drugs. Chemistry \& biology. 2010; 17: 421433.

32. Yang F, Teves SS, Kemp CJ, Henikoff S. Doxorubicin, DNA torsion, and chromatin dynamics. Biochimica et biophysica acta. 2014; 1845: 84-89.

33. Rauch A, Hennig D, Schäfer C, Wirth M, Marx C, Heinzel T, Schneider G, Krämer OH. Survivin and YM155: how faithful is the liaison? Biochimica et biophysica acta. 2014; 1845: 202-220.

34. Kirch HC, Flaswinkel S, Rumpf H, Brockmann D, Esche H. Expression of human $\mathrm{p} 53$ requires synergistic activation of transcription from the 53 promoter by AP-1, NF-kappaB and Myc/Max. Oncogene. 1999; 18: 2728-2738.

35. Endo F, Nishizuka SS, Kume K, Ishida K, Katagiri H, Ishida K, Sato K, Iwaya T, Koeda K, Wakabayashi G. A compensatory role of NF-kappaB to p53 in response to 5-FU-based chemotherapy for gastric cancer cell lines. PloS one. 2014; 9: e90155.

36. Lehmann A, Denkert C, Budczies J, Buckendahl AC, DarbEsfahani S, Noske A, Muller BM, Bahra M, Neuhaus P, Dietel M, Kristiansen G, Weichert W. High class I HDAC activity and expression are associated with RelA/p65 activation in pancreatic cancer in vitro and in vivo. BMC cancer. 2009; 9: 395.

37. Fritsche P, Seidler B, Schuler S, Schnieke A, Göttlicher M, Schmid RM, Saur D, Schneider G. HDAC2 mediates therapeutic resistance of pancreatic cancer cells via the BH3-only protein NOXA. Gut. 2009; 58: 1399-1409.

38. Dalmases A, Gonzalez I, Menendez S, Arpi O, Corominas JM, Servitja S, Tusquets I, Chamizo C, Rincon R, Espinosa L, Bigas A, Eroles P, Furriol J, Lluch A, Rovira A, Albanell $\mathrm{J}$ et al. Deficiency in p53 is required for doxorubicin induced transcriptional activation of NF-kB target genes in human breast cancer. Oncotarget. 2014; 5: 196-210.

39. Gao Z, Chiao P, Zhang X, Zhang X, Lazar MA, Seto E, Young HA, Ye J. Coactivators and corepressors of NFkappaB in IkappaB alpha gene promoter. The Journal of biological chemistry. 2005; 280: 21091-21098.

40. Saldana-Meyer R, Recillas-Targa F. Transcriptional and epigenetic regulation of the p53 tumor suppressor gene. Epigenetics : official journal of the DNA Methylation Society. 2011; 6: 1068-1077.

41. Gareau JR, Lima CD. The SUMO pathway: emerging mechanisms that shape specificity, conjugation and recognition. Nature reviews. Molecular cell biology. 2010; 11: 861-871.

42. Chen L, Fischle W, Verdin E, Greene WC. Duration of nuclear NF-kappaB action regulated by reversible acetylation. Science. 2001; 293: 1653-1657.

43. Kiernan R, Bres V, Ng RW, Coudart MP, El Messaoudi S, Sardet C, Jin DY, Emiliani S, Benkirane M. Post-activation turn-off of NF-kappa B-dependent transcription is regulated by acetylation of $\mathrm{p} 65$. The Journal of biological chemistry. 2003; 278: 2758-2766.

44. Chen Y, Wang H, Yoon SO, Xu X, Hottiger MO, Svaren J, Nave KA, Kim HA, Olson EN, Lu QR. HDAC-mediated deacetylation of NF-kappaB is critical for Schwann cell myelination. Nature neuroscience. 2011; 14: 437-441.

45. Schwitalla S, Ziegler PK, Horst D, Becker V, Kerle I, Begus-Nahrmann Y, Lechel A, Rudolph KL, Langer R, Slotta-Huspenina J, Bader FG, Prazeres da Costa O, Neurath MF, Meining A, Kirchner T, Greten FR. Loss of p53 in enterocytes generates an inflammatory microenvironment enabling invasion and lymph node metastasis of carcinogeninduced colorectal tumors. Cancer cell. 2013; 23: 93-106.

46. Ellis L, Atadja PW, Johnstone RW. Epigenetics in cancer: targeting chromatin modifications. Molecular cancer therapeutics. 2009; 8: 1409-1420.

47. Bunz F, Dutriaux A, Lengauer C, Waldman T, Zhou S, Brown JP, Sedivy JM, Kinzler KW, Vogelstein B. Requirement for p53 and p21 to sustain G2 arrest after DNA damage. Science. 1998; 282: 1497-1501.

48. Ropero S, Fraga MF, Ballestar E, Hamelin R, Yamamoto H, Boix-Chornet M, Caballero R, Alaminos M, Setien F, Paz MF, Herranz M, Palacios J, Arango D, Orntoft TF, Aaltonen LA, Schwartz S, Jr. et al. A truncating mutation of HDAC2 in human cancers confers resistance to histone 
deacetylase inhibition. Nature genetics. 2006; 38: 566-569.

49. Wilting RH, Yanover E, Heideman MR, Jacobs H, Horner J, van der Torre J, DePinho RA, Dannenberg JH. Overlapping functions of Hdac1 and $\mathrm{Hdac} 2$ in cell cycle regulation and haematopoiesis. The EMBO journal. 2010; 29: 2586-2597.

50. Brummelkamp TR, Bernards R, Agami R. A system for stable expression of short interfering RNAs in mammalian cells. Science. 2002; 296: 550-553.

51. Brostjan C, Anrather J, Csizmadia V, Natarajan G, Winkler H. Glucocorticoids inhibit E-selectin expression by targeting NF-kappaB and not ATF/c-Jun. Journal of immunology. 1997; 158: 3836-3844.

52. Bier C, Knauer SK, Klapthor A, Schweitzer A, Rekik A, Krämer OH, Marschalek R, Stauber RH. Cell-based analysis of structure-function activity of threonine aspartase 1. The Journal of biological chemistry. 2011; 286: 3007 3017.

53. Dosch T, Horn F, Schneider G, Kratzer F, Dobner T, Hauber J, Stauber RH. The adenovirus type 5 E1B-55K oncoprotein actively shuttles in virus-infected cells, whereas transport of E4orf6 is mediated by a CRM1-independent mechanism. Journal of virology. 2001; 75: 5677-5683.

54. Stauber RH, Knauer SK, Habtemichael N, Bier C, Unruhe B, Weisheit S, Spange S, Nonnenmacher F, Fetz V, Ginter T, Reichardt S, Liebmann C, Schneider G, Krämer OH. A combination of a ribonucleotide reductase inhibitor and histone deacetylase inhibitors downregulates EGFR and triggers BIM-dependent apoptosis in head and neck cancer. Oncotarget. 2012; 3: 31-43.

55. Schneider G, Saur D, Siveke JT, Fritsch R, Greten FR, Schmid RM. IKKalpha controls p52/RelB at the skp2 gene promoter to regulate G1- to S-phase progression. The EMBO journal. 2006; 25: 3801-3812.

56. Baumann S, Dostert A, Novac N, Bauer A, Schmid W, Fas SC, Krueger A, Heinzel T, Kirchhoff S, Schutz G, Krammer PH. Glucocorticoids inhibit activation-induced cell death (AICD) via direct DNA-dependent repression of the CD95 ligand gene by a glucocorticoid receptor dimer. Blood. 2005; 106: 617-625.

57. Buchwald M, Pietschmann K, Brand P, Günther A, Mahajan NP, Heinzel T, Krämer OH. SIAH ubiquitin ligases target the nonreceptor tyrosine kinase ACK1 for ubiquitinylation and proteasomal degradation. Oncogene. 2013; 32: 49134920.

58. Baumbusch LO, Myhre S, Langerod A, Bergamaschi A, Geisler SB, Lonning PE, Deppert W, Dornreiter I, Borresen-Dale AL. Expression of full-length p53 and its isoform Deltap53 in breast carcinomas in relation to mutation status and clinical parameters. Molecular cancer. 2006; 5: 47. 